\title{
Metal-loaded porous polyhydroxylic matrices with improved antibacterial properties
}

\author{
Farzaneh Noori ${ }^{1}$, Neree-Armelle Tchoumi ${ }^{2}$, Meriem Megoura ${ }^{2}$, Mircea Alexandu \\ Mateescu $^{2}$, and Abdelkrim Azzouz ${ }^{1}$ \\ ${ }^{1}$ University of Quebec in Montreal \\ ${ }^{2}$ University of Quebec at Montreal Department of Chemistry
}

July 7,2020

\begin{abstract}
Metal-loaded porous matrices based on clay and cellulose materials displayed appreciable antibacterial activity against Escherichia coli DH5 $\alpha$ and Bacillus subtilis 168. BoltornTMH20 polyol dendrimer supported by montmorillonite and cellulose turned out to be effective porous matrices for $\mathrm{Cu} 0$ and $\mathrm{Ag} 0$ nanoparticles dispersion. The resulting organoclay and polyol-coated cellulose were found to stabilize $\mathrm{Cu} 0$ and $\mathrm{Ag} 0$ nanoparticles through their terminal hydroxyl groups. This was explained in terms of Lewis Acid-Base interaction between the electron pair of the oxygen atom belonging to the terminal hydroxyl and metal species as supported by XPS data. The metal retention strength was found to correlate with the antibacterial activity, surface basicity and hydrophilic character. These findings are of great importance, because they open promising prospects for vegetal fibers and clay-supported drugs to treat dermatological and gastro-intestinal infections.
\end{abstract}

\section{Keywords}

Organoclays; Cellulose; Metal Nanoparticles, Porous Polyhydroxylic Matrices; Antibacterial Properties; Xray Photoelectron Spectroscopy

\section{Short running title}

\section{Novel metal-polyol-based antibacterial agents}

\section{Introduction}

Resistance of pathogenic bacteria against antibiotics has become a major medical and pharmaceutical issue. Overuse of antibiotics has been identified as a main cause of pathogenic adaptation of bacteria. Numerous outbreaks of infectious diseases have been reported as a direct effect of antibiotic resistance (Levy, 1998), which still remains a major challenge to be addressed (Cragg \& Newman, 2013). Metals are known as metabolism disturbing agents, some of them being harmful for animals and human (Martin \& Griswold, 2009). Certain zero-valence metals (metal-zero) such as silver in high dispersion state have long been used in treating skin bacterial infections (Rai, Yadav, \& Gade, 2009). Nanoparticles of gold, zinc and titanium have showed high bioactivity. In this context, silver $(\mathrm{Ag})$ and copper $(\mathrm{Cu})$ are also promising nanoparticles that have shown broad-spectrum activity against many species of Gram positive and Gram-negative bacteria (Carretero, 2002; Čık, Bujdáková, \& Šeršeň, 2001; Č́́k et al., 2006; Costa, Conte, Buonocore, \& Del Nobile, 2011; Dizman, Badger, Elasri, \& Mathias, 2007; Gupta, Maynes, \& Silver, 1998; Herrera, Burghardt, \& Phillips, 2000).

Higher performant antibacterial activity is obtained if $\mathrm{Ag}$ and $\mathrm{Cu}$ nanoparticles are finely and uniformly sized (España, Sarkar, Biswas, Rusmin, \& Naidu, 2019). When highly dispersed, metal nanoparticles (MNP) can 
be active against pathogenic bacteria without inducing bacterial resistance (España et al., 2019). However, MNPs have a strong tendency to aggregate into bulky inactive clusters (Rees, Zhou, \& Compton, 2011). Polyhydroxylated compounds and polyamines bear specific chemical groups that confer them chelating and stabilizing properties for metals (Crooks, Zhao, Sun, Chechik, \& Yeung, 2001). Functionalized polymers could exhibit higher effectiveness when supported on solid surfaces (Hellmann et al., 1998). The resulting inorganic-organic matrices hosting metal nanoparticles (Scheme 1) are a novel class of antibacterial agents displaying high surface-to-volume ratio, chemical stability, thermal resistance, non-toxicity and recyclability (Bragg \& Rainnie, 1974). Their synthesis has become the main target of the present research.

\section{Scheme 1}

The interest of this research consists in using inorganic natural alumino-silicates such as clay minerals, known to be harmless for human health and biodiversity. Among these, smectite-type sodium montmorillonite (NaMt) could be an interesting host matrice for metals due to its natural abundance, cost effectiveness, non-toxicity, chemical inertness, sorptive capabilities, large specific surface area (Komadel, 2016) and even beneficial medicinal effects (Carretero, 2002; Nadziakiewicza, Kehoe, \& Micek, 2019). .

To overcome this problem, inorganic carriers such as clay minerals for metal nanoparticles have been investigated (Kim et al., 2007). Successful attempts against bacteria were already achieved using other clay minerals such as allophane and imogolite doped with metals like $\mathrm{Ag}, \mathrm{Cu}, \mathrm{Co}$, $\mathrm{Zn}$ (Stavitskaya et al., 2019; Williams et al., 2011). Attempts were also achieved using functionalized clay minerals and vegetal fibers for the dispersion of silver and copper ions (Joshi, Purwar, Udakhe, \& Sreedevi, 2015).

High adsorptive capabilities for metal nanoparticles in NaMt are largely responsible for the antimicrobial properties of the metal-clays. The adsorptive properties in NaMt are governed by a large specific surface area with increased net negative charges on the sheets that can be obtained by intercalation of NaMt with dendritic polyols like Boltorn ${ }^{\mathrm{TM}}$ H20 (Vdović, Jurina, Škapin, \& Sondi, 2010). Reportedly, eco-friendly and cost-effective cotton fabric-based composite materials doped with copper oxide showed antibacterial action against Staphylococcus epidermis and Escherichia coli(Nabil, Christine, Julien, \& Abdelkrim, 2018). The aim of this work was to prepare organoclays and/or natural polymers for hosting metal nanoparticles with long-term antibacterial effects.

Deeper insights in metal-matrice interaction will allow tailoring optimal interactions with MNPs by modifying the type and number of chemical functions of the organic moiety. This is expected to influence the metal to be released, the release velocity and desired antibacterial activity. This concept allows envisaging diverse applications for controlled release of a wide variety and drugs and other medicinal molecules.

\section{Materials and methods}

\subsection{Chemicals}

All chemicals were of analytical grade and used without previous purification. Crude bentonite (SigmaAldrich, Oakville, Canada), sodium chloride (NaCl) (ACP chemicals, Montreal, Canada), copper acetate $\left(\mathrm{Cu}\left(\mathrm{CH}_{3} \mathrm{COO}\right)_{2}\right)$ (Fisher chemicals, Ottawa, Canada), silver nitrate $\left(\mathrm{AgNO}_{3}\right)$ (Fisher chemicals), sodium borohydride $98 \%\left(\mathrm{NaBH}_{4}\right)$ (Acros organics, Ottawa, Canada), copper nitrate $\left(\mathrm{Cu}\left(\mathrm{NO}_{3}\right)_{2}\right)$ (Anachemia VWR company, Montreal, Canada), Boltorn H20 (Perstorp, Malmo, Sweden), absolute methanol (MeOH) (SigmaAldrich), toluene (Sigma-Aldrich) were used. All experiments were performed in distilled water. Non-woven cellulose tissue (gauze) denoted as CT was purchased from PJC, Canada.

\subsection{Polyol and metal dispersion}

Sodium-montmorillonite (NaMt) was obtained through combined ion-exchange of crude bentonite (Aldrich) in aqueous $\mathrm{NaCl}$ solution using an effective procedure fully described elsewhere (Scheme S1 ) (Abdelkrim Azzouz et al., 2010; Thuc et al., 2010). This was followed by adding $200 \mathrm{~g}$ of NaMt to a 41.2:58.8 volume ratio $\mathrm{MeOH} / \mathrm{H}_{2} \mathrm{O}$ mixture containing $200 \mathrm{mg}$ of Boltorn $\mathrm{H} 20$ polyol dendrimer under continuous stirring for $1 \mathrm{~h}$ at $40-60^{\circ} \mathrm{C}$. The resulting organoclay, denoted as H20@NaMt was died overnight in a freeze-drying device. 
Similarly, Boltorn H20 was also dispersed on cellulose tissue (CT) by impregnation in $20 \mathrm{~mL}$ of $0.01 \mathrm{~mol} / \mathrm{L}$ Boltorn ${ }^{\mathrm{TM}} \mathrm{H} 20$ aqueous solution at room temperature (RT) for 1h, resulting in a H20@CT composite.

An amount of $0.2 \mathrm{~g}$ of NaMt-H20 was slowly mixed in a $50 \mathrm{~mL}$ beaker with $15 \mathrm{~mL}(33.33 \%$ and $66.66 \%$ toluene/water) aqueous solution of $0.12 \mathrm{~mol} / \mathrm{L} \mathrm{Cu}\left(\mathrm{CH}_{3} \mathrm{COO}\right)_{2}$ and $\left(\mathrm{AgNO}_{3}\right)$ under vigorous stirring for $2 \mathrm{~h}$. Both organoclay suspensions were dried overnight at room temperature, resulting in a first series of cationloaded organoclays denoted as $\mathrm{Cu}^{2+} / \mathrm{H} 20 @ \mathrm{NaMt}$ and $\mathrm{Ag}^{+} / \mathrm{H} 20 @ \mathrm{NaMt}$. A second series of samples was prepared by dropwise adding $10 \mathrm{~mL}$ aqueous solution of $\mathrm{NaBH}_{4}(0.2 \mathrm{~mol} / \mathrm{L})$ to both organoclay suspensions during 15 min under a nitrogen stream at ambient conditions (Scheme S2 ). The resulting metal-zeroloaded organoclays, denoted as $\mathrm{Cu}^{0} / \mathrm{H} 20 @ \mathrm{NaMt}$ and $\mathrm{Ag}^{0} / \mathrm{H} 20 @ \mathrm{NaMt}$ were further repeatedly washed with distilled water to eliminate the excess of $\mathrm{Cu}^{2+}$ and $\mathrm{Ag}^{+}$cations and then dried overnight. Further, for the preparation of metal loaded $\mathrm{H} 20 @ \mathrm{CT}$ samples, $0.8 \mathrm{~g}$ of $\mathrm{AgNO}_{3}$ or $1.24 \mathrm{~g}$ of $\mathrm{Cu}\left(\mathrm{NO}_{3}\right)_{2}$ were each dissolved in $30 \mathrm{~mL}$ of distilled water and mixed with $1 \mathrm{~g}$ and $1.5 \mathrm{~g}$ of $\mathrm{NaBH}_{4}$, respectively in order to reduce $\mathrm{Cu}^{2+} \mathrm{and} \mathrm{Ag}^{+}$ into $\mathrm{Cu}^{0}$ and $\mathrm{Ag}^{0}$ nanoparticles (denoted as $\mathrm{AgNP}_{\mathrm{S}}$ and $\mathrm{CuNP}_{\mathrm{S}}$,). This was achieved upon stirring for 5-6h at room temperature (RT), under nitrogen stream to prevent MNP oxidation. The resulting $\mathrm{Ag}^{0} / \mathrm{H} 20 @ \mathrm{CT}$ and $\mathrm{Cu}^{0} / \mathrm{H} 20 @ \mathrm{CT}$ samples were dried overnight at RT in a sealed enclosure containing dry $\mathrm{O}_{2}$-free nitrogen dried with $\mathrm{NaOH}$ pellets.

\subsection{Material characterization}

The basicity and hydrophilic character of the as-prepared samples were assessed through TPD of $\mathrm{CO}_{2}$ and water (A Azzouz et al., 2006; Beltrao-Nunes et al., 2019; Terrab et al., 2016). This was obtained by putting $45-50 \mathrm{mg}$ of each sample at heating rate of $5{ }^{\circ} \mathrm{C} \cdot \mathrm{min}^{-1}$ from $20{ }^{\circ} \mathrm{C}$ to $450{ }^{\circ} \mathrm{C}$ and under a nitrogen stream of 5 $\mathrm{mL} \cdot \mathrm{min}^{-1}$ after saturation of each sample with $\mathrm{CO}_{2}$ gas (Scheme. S3 ). Deeper insights into the structure of the as-synthesized $\mathrm{MNP}_{\mathrm{S}} / \mathrm{H} 20 @ \mathrm{NaMt}$ and $\mathrm{MNP}_{\mathrm{S}} / \mathrm{H} 20 @ \mathrm{CT}$ materials were achieved through TG Analysis (TA Instruments TGA (Q500)/Discovery MS equipment). For this purpose, 4-7 mg samples were heated in platinum $(\mathrm{Pt})$ pan at a temperature range of $20-500{ }^{\circ} \mathrm{C}$ and $10{ }^{\circ} \mathrm{C} / \mathrm{min}$ heating rate under $30 \mathrm{~mL} / \mathrm{min}$ dry argon stream (Fig. S1 ). The particle morphology of the material was screened by SEM (Jeol JCM6000 PLUS instrument). The samples were spread as powder on conductive double adhesive carbon tapes (Fig. S2 ). The SEM analysis of non-conductive samples was performed at $1.0 \mathrm{kV}$ voltage, versus $15 \mathrm{kV}$ for metal-containing materials (conductive). The crystalline structure was investigated by XRD in 2-Theta range 10-80, using $\mathrm{CuK}_{\text {alpha }}$ radiation (1.5406 $\AA$ ) and XRD D8 Advance device (Fig. S3 ). Metal-matrices interactions were assessed through XPS of $7800 \times 300 \mu \mathrm{m}$ spots by means of an AXIS-ULTRA instrument (by KRATOS Analytical Ltd, UK) and a monochromatic Al-based X-ray source (260 watts in constant pass energy mode in two $160 \mathrm{eV}$ and $1 \mathrm{eV}$ steps).

\subsection{Antibacterial tests}

Approximatively $74 \times 10^{6}$ colony forming units CFU.mL ${ }^{-1}$ of each bacteria species (E. coli and B. subtilis 168) with a cell density of 0.5 at $600 \mathrm{~nm}$ was loaded on LBA plates. The antimicrobial behavior of the as-prepared samples was evaluated by diffusion and zone Inhibitory tests towards E. coliand B. subtilis bacterial strains. The assay is a semi-quantitative method where samples (1-9 mg) containing silver or copper metal were put in direct contact on LBA plate pre-seeded by bacteria strains. Negative controls were included in each assay. After $24 \mathrm{~h}$ of incubation at $37^{\circ} \mathrm{C}$, the diffusion zone where bacteria proliferation was inhibited was measured. The antibacterial property was evaluated by the application of $5 \mathrm{mg}$ (Organoclays) or $1 \times 0.5 \mathrm{~mm}^{2}$ (CT) of the synthesized clay-based materials or tissue of cellulose-based samples, respectively. All experiments were performed in triplicate (three independent growth cultures) with at least two technical replicates.

\section{RESULTS AND DISCUSSION}

\subsection{Changes upon metal incorporation}

The formation of CuNPs and AgNPs dispersed into polyol-modified matrices was illustrated by marked color changes. The most visible changes took place from blue to black and accounts for $\mathrm{Cu}^{2+}$ conversion into $\mathrm{Cu}^{0}$ in the presence of $\mathrm{NaBH}_{4}$ as a reduction agent. However, a less visible color change was noticed for $\mathrm{Ag}^{+}$ 
conversion into $\mathrm{Ag}^{0}$ in the solution (Fig. S4.a). These changes are much more pronounced in dry powders of H20@NaMt modified by $\mathrm{Cu}^{0}$ and $\mathrm{Ag}^{0}$ and their cationic forms (Fig. S4.b ). The same results were observed for similar metal insertion in the presence of H20@CT-based samples. (Fig. S5).

Metal incorporation was confirmed by visible modification of the morphology of surface of the host-material. Preliminary observation through optical microscopy revealed a transition from a clean and almost soft surface of NaMt to the appearance of grains on the surfaces of both $\mathrm{Cu}^{0} / \mathrm{NaMt}$ and $\mathrm{Ag}^{0} / \mathrm{NaMt}$ (Fig. S6 ). This provides evidence of the formation of metal particles. Similar observations were made on CT-based materials (Fig. S7 ). This was confirmed by additional analysis through of SEM images of MNP-loaded NaMt and H20@CT (Fig. 1.a). The appearance of grains smaller than $100 \mathrm{~nm}$ indicates that metal salt reduction using $\mathrm{NaBH}_{4}$ effectively produced spheroidal nanoparticles with and without polyol as dispersing agent, as illustrated by the behavior of NaMt alone and H20-coated CT material. This can also be seen with CT alone (Fig. S8). The SEM images of NaMt showed specific morphology changes of lamellar structure according to the metal inserted (Fig. 1.a ). Larger crystalline rods were observed on NaMt-Cu, presumably due to residual $\mathrm{Cu}^{2+}$ salt.

\section{Figure 1}

\subsection{Effect polyol incorporation on metal dispersion}

The non-uniform dispersion of MNPs must be due to the heterogeneous density of the small amount of hydroxyl groups belonging to the incorporated H20 poly dendrimer on the CT surface. Incorporation of polyol appears to act as the main dispersing agent of MNP, favoring complete metal entrapping by surrounding $\mathrm{OH}$ groups. This must take place through stronger Polyol-HO:Metal interaction that consumes all available $\mathrm{OH}$ groups of the inserted dendrimer at the expense of H20@CT surface association. This explains the presence of Polyol:MNP composite scales unstuck on the CT surface (Fig. 1.b ). Similar observations can be made with Ag-modified materials, except the fact that metal salt needles apparently occur in much higher density. This corresponds to a relatively higher amount of residual unreduced $\mathrm{Ag}$ salt, i.e. less $\mathrm{Ag}^{0}$ compared to copperloaded materials. This lower reduction level of $\mathrm{Ag}^{+}$cations suggests a lower amount of $\mathrm{Ag}^{0}$ atoms. This could explain somehow the paradoxically weaker antibacterial activity of Ag-based materials as compared to their $\mathrm{Cu}$ counterparts, given that silver is expected to display higher performance in this regard. A partial explanation resides in the stronger capacity of copper to undergo oxidative processes as compared to silver. The involvement of the $\mathrm{OH}$ groups in metal stabilization can be explained by changes in the hydrophilic character and basicity of the host materials. Deeper insights in this regard were achieved through TPD measurements.

\subsection{Changes in clay surface basicity}

The TPD patterns revealed the occurrence of at least four basicity strengths, namely weakly (below $100^{\circ} \mathrm{C}$ ), medium (between 100 and $250^{\circ} \mathrm{C}$ ), medium-to-strong (between 300 and $450^{\circ} \mathrm{C}$ ) and strong basicity (between 450 and $550^{\circ} \mathrm{C}$ ). The slight shift of the desorption peak from $60-200^{\circ} \mathrm{C}$ towards higher temperatures (170$220^{\circ} \mathrm{C}$ ) was noticed from bentonite to NaMt (Fig. S9-a ). This indicates a slight strengthening of the surface basicity, presumably due to the removal of acidic silica phases (quartz, sand, cristobalite). This agrees with the slight increase in the CRC value after bentonite purification from 2101 to $2261 \mathrm{mmol}_{\mathrm{g}}{ }^{-1}$ (Table 1 ) which indicates that bentonite purification induces a slightly higher number of stronger basic sites.

\section{Table 1}

This is well supported by the marked depletion of the XRD belonging to Quartz in bentonite and montmorillonite patterns (denoted as Q), and the presence of the main XRD lines of crystalline silica in the pattern of the residual ash (Fig. S10 ). A shift of the 001 XRD line from a $2 \vartheta$ value of $7.357 @$ for bentonite to 9.142@ was noticed for NaMt, indicating a decrease in the interlayer spacing. This shift is a special feature of the lamellar structure and is due to the replacement of bulky impurity particles by sodium cations. This was confirmed by the noticeable sharpening and increased intensity of the main XRD lines, which is a special feature of homo-ionic form of montmorillonite and almost perfect parallel arrangements of the clay sheets. 
The $\mathrm{Na}^{+}$cation has a lower polarizing power and thereby lower intrinsic acidity and weaker capacity to attract water molecules than multivalent cations. This somehow explains the lower WRC value observed for NaMt compared to bentonite. MNP incorporation induced a marked decrease in CRC, due to at least two kinds of competitive interactions. Some MNP interactions occur with the lattice oxygen atoms (-Si-O-Siwith strong Lewis basicity). Other interactions take place between the $\mathrm{OH}$ groups of both terminal in-plane silanols and out-of-plane Si-OH with weaker basicity and MNPs on the surface (Sulpizi, Gaigeot, \& Sprik, 2012).

\subsection{Changes in CT surface basicity}

The TDP measurements revealed no $\mathrm{CO}_{2}$ desorption peak for untreated cellulose in the temperature range $20-100^{\circ} \mathrm{C}$. Polyol incorporation induced a marked change in the TPD profile, mainly characterized by the appearance of a wide desorption peak between 20 and $110^{\circ} \mathrm{C}$ (Fig. S9.b ). This accounts for the rise of weakly basic adsorption sites, most likely amphoteric to slightly basic $\mathrm{OH}$ groups belonging to the inserted polyol dendrimer. $\mathrm{OH}$ groups were found to dramatically decline after CuNP insertion and totally disappear after AgNP incorporation. This is a confirmation of the appearance rise of novel HO:MNP interaction that seems to be stronger with AgNPs compared to CuNPs. Thus, CuNPs seem to be less entrapped by the dendrimer entanglement than AgNPs and more effective as antibacterial agent being less retained in the solid phase.

\subsection{Thermal assessment of the affinity towards aqueous media}

The antibacterial activity of MNP-loaded materials is often determined by their affinity towards aqueous media where bacteria live. This affinity towards water can be evaluated by TGA (Fu et al., 2015). The TGA patterns (Fig. S11.a ) revealed a single and small weight loss (WL) of at most $0.7-0.8 \%$ for NaMt between 20 and $120^{\circ} \mathrm{C}$. This corresponds to reversible dehydration, as shown by repeated TGA analysis of rehydrated samples. The total absence of other weight losses and more particularly of dehydroxylation (2 -Si-OH Si-O-Si- $+\mathrm{H}_{2} \mathrm{O}$ ) at higher temperature provided evidence that NaMt is stable throughout the entire range of temperature investigated. MNP insertion into NaMt gave rise to a marked endothermic process at ca. $140-480{ }^{\circ} \mathrm{C}$ for $\mathrm{Cu}^{0} / \mathrm{NaMt}$ and $90-470{ }^{\circ} \mathrm{C}$ for $\mathrm{Ag}^{0} / \mathrm{NaMt}$. This accounts for $6.6 \%$ and $9.4 \% \mathrm{WL}$, respectively (Table 2 ).

\section{Table 2}

Within this temperature range, an initial mass loss was registered for $\mathrm{NaMt}-\mathrm{Cu}^{0}$ up to $180{ }^{\circ} \mathrm{C}$, and must still be due to the dehydration process. This dehydration over a larger temperature range can be explained by an additional contribution of retained moisture on the incorporated metal. A second WL can be seen up to $470-480{ }^{\circ} \mathrm{C}$ and could be related to a dehydroxylation of terminal Metal-OH groups of possible metal oxide particles. The latter may unavoidably be produced during the synthesis procedure through slight metal oxidation when contacted to air. Another explanation should consist in a possible slow release of moisture from the internal surface the metal loaded clay mineral. Both WL were found to shift towards lower temperatures but with higher WL values in $\mathrm{Ag}^{0} / \mathrm{NaMt}$, indicating a higher hydrophilic character. In contrast, CT-based samples were mostly characterized by a much lower moisture loss (Fig. S11.b), which indicates a much weaker hydrophilic character. This must be due to the fact that commercial untreated CT displays negligible surface density of hydroxyl groups. Polyol incorporation appeared to slightly improve this feature, by introducing high amount of $\mathrm{OH}$ groups. Incorporation of MNPs alone or accompanied by polyol H20 induced a marked enhancement of the hydrophilic character. This is supported by more pronounced weight loss in the temperature range of $47-200{ }^{\circ} \mathrm{C}$ up to $8.25 \%\left(\mathrm{Cu}^{0} / \mathrm{CT}\right), 9.74 \%\left(\mathrm{Ag}^{0} / \mathrm{CT}\right), 4.675 \%$ $\left(\mathrm{Cu}^{0} / \mathrm{H} 20 @ \mathrm{CT}\right)$ and $8.525 \%\left(\mathrm{Ag}^{0} / \mathrm{H} 20 @ \mathrm{CT}\right)$ (Table 2 ).

\subsection{Evidence of metal dispersion}

Evidence of metal dispersion in the investigated materials was provided by X-Ray photoelectron spectroscopy (XPS). Changes in the binding energy (BE) of the electrons belonging to the material atoms involved in metal dispersion are expected to provide valuable information about the retention strength of MNP and 
indirectly on the antibacterial activity. The presence of metal in the chemical compositions of NaMt and CT after metal incorporation was revealed by new XPS signals, i.e. Cu2p at $933 \mathrm{eV}$ and Ag3d at $364 \mathrm{eV}$ (Fig. 2.a) .

Fig. 2

\section{Table 3}

The most important XPS results reside in the shifts of the binding energy (BE) of the key elements (oxygen, silicon and aluminum)(Table 3) providing evidence of the occurrence of metal interaction with the host surface. For oxygen, the BE value decreased from $532.55 \mathrm{eV}$ down to $531.00 \mathrm{eV}$ and $527.00 \mathrm{eV}$ upon $\mathrm{Cu}$ and $\mathrm{Ag}$ incorporation in NaMt samples, respectively. Similar sequence was noticed in H20@CT, but with much weaker BE decrease from $533.00 \mathrm{eV}$ down to $531.65 \mathrm{eV}$ and $531.74 \mathrm{eV}$ after $\mathrm{Cu}$ and $\mathrm{Ag}$ incorporation. This suggests weaker metal retention in this organic composite. Such a BE weakening indicates lower electron binding to their parent-atom due to an attraction by next-neighboring species, and can be explained in terms of Lewis-Acid-Base (LAB) interaction between lattice oxygen and MNPs. This indicates weaker interaction with CuNPs as compared to AgNPs in both materials, and weaker retention strength of both metals in H20@CT.

BE decay was also noticed for $\mathrm{Si}$ and $\mathrm{Al}$ atoms from 1383.20 to 103 and 1411.29 to 75 , respectively, suggesting additional MNP interactions with the aluminosilicate surface (Fig. 2.b) . The presence of a C1s signal in clay samples may be due to $\mathrm{CaCO}_{3}$, as supported by the XRD pattern of bentonite with 113, 202 and 018 plane families between 40-45 degrees. XPS data, more particularly for cellulose-based samples (Fig. S12 ) showed no significant BE shift for $\mathrm{C}$ atom, indicating that carbon interaction with MNP, if any, is negligible.

3.7. Metal-induced antibacterial activity

E. coli $\mathrm{DH} 5 \alpha$ and B. subtilis 168 were used as model species to evaluate mass transfer from the clay to bacteria. The 24 hours of incubation at $37{ }^{\circ} \mathrm{C}$ of untreated host matrices (NaMt, Boltorn ${ }^{\mathrm{TM}} \mathrm{H} 20$ and H20@NaMt) with a population of $74.10^{6} \mathrm{CFU} \cdot \mathrm{mL}^{-1}$ revealed no antibacterial activity in three independent experiments with bothE. coli and B. subtilis strains. For conciseness, only data obtained with B. subtilis were mentioned herein (Fig. 3.a) . In contrast, copper-loaded $(\mathrm{Cu} / \mathrm{NaMt})$ and silver-loaded $(\mathrm{Ag} / \mathrm{NaMt})$ clays exhibited noticeable antibacterial activity (Fig. 4), demonstrating that clay minerals can behave as MNP-hosting matrices. This improvement would be due to metal incorporation (Gordon et al., 2010; Potera, 2012; Vincent, Duval, Hartemann, \& Engels-Deutsch, 2018; Yun'an Qing et al., 2018) but the mechanisms remain to be elucidated..

Fig. 4

3.8. Effect of metal dispersion upon dendrimer incorporation

The effect metal dispersion in dendrimer and their antibacterial activity were investigated by incubating silver and copper organoclay samples with bacteria. The results showed that the mere incorporation of metals regardless to the oxidation state induces antibacterial activity, slightly higher for the cationic form (Fig. 5).

Fig. 5

The presence of dendrimer seems to play a key-role producing higher antibacterial activity as compared to $\mathrm{Cu}^{0} / \mathrm{NaMt}$ and $\mathrm{Ag}^{0} / \mathrm{NaMt}$. This can be due to a higher metal dispersion within the dendrimer entanglement bearing $\mathrm{OH}$ groups that act as chelating agents (Lewis base) through their oxygen atoms. This was well supported by a marked increase in the inhibition zone diameter (Table S1). These data also revealed that both $\mathrm{Cu}^{0}$ and $\mathrm{Cu}^{2+}$ are more effective than both silver forms. This can be explained by an easier release of copper (both zero and bivalent forms) in the liquid media due to lower BE shifts (as measured by XPS), as compared to silver. Also, copper is more reactive than silver, generating oxygen reactive species (ROS) as in Fenton-like and Haber-Weiss processes. Other possible contributions should be ascribed to lower amounts: (i) of inserted $\mathrm{Ag}^{0}$ atoms probably because of the lower reduction level of $\mathrm{Ag}^{+}$cations and (ii) of dispersed 
$\mathrm{Ag}^{+}$cation, chelated and stabilized by the polyol moiety. This was supported by SEM images (Fig. 1.a ) that show large amount of non-dispersed rod-like silver salt crystals indicating a rigorous concordance between the material characterization data and antibacterial activity. Highest antibacterial ability was observed against Gram-positive B. subtilis, as illustrated by the largest inhibition zone diameter of $2.73 \pm 0.17 \mathrm{~cm}$ (Table S1).This can be due to the very structure of the Bacillus cell wall with peptidoglycan multilayers and an abundant amount of pores that confers them more sensitivity to reactive species as compared to Gram-negative E. coli (Fu et al., 2015).

\subsection{Effect of the amount of metal-loaded organoclay}

Deeper insights through different amounts of metal-loaded organoclays ranging from 1 to $9 \mathrm{mg}$ were achieved to confirm the effect of MNP insertion on their antibacterial activity. A first overview of the obtained results revealed that the bacterial growth was inhibited after an incubation with $1 \mathrm{mg}$ antimicrobial agents (Fig. 3.b) . The average diameter of the inhibition zone was of $2-2.3 \mathrm{~cm}$ for $\mathrm{Cu}^{2+} / \mathrm{H} 20 @ \mathrm{NaMt}$ and $0.8-2 \mathrm{~cm}$ $\mathrm{Ag}^{+} / \mathrm{H} 20 @$ NaMt (Table S2 ). This result can be ascribed to the strong antibacterial capacity of metalloaded organoclay matrices on E. coli and Bacillus. The appearance of antibacterial activity seems due to the metal incorporation, regardless to its oxidation state. In other words, the mere presence of metal species appears to promote an antibacterial activity. This is well argued by the fact that no antibacterial activity was found for both clay mineral and polyol alone (Fig. 3.a). Therefore, the biocide effect of the as-synthesized samples should be due to the action of both MNPs and metal cations. The diameter of the inhibition zone of both strains $E$. coli and B. subtilis increased almost proportionally with increasing amount of bactericidal agents up to a certain level. Maximal values of 2.5 and $3.5 \mathrm{~cm}$ for $9 \mathrm{mg}$ of $\mathrm{Cu}^{2+} / \mathrm{NaMt} @ \mathrm{H} 20$ and of 2.4 and $3 \mathrm{~cm}$ for the same amount of $\mathrm{Cu}^{0} / \mathrm{NaMt} @ \mathrm{H} 20$ against E. coli and B. subtilis, were respectively attained (Table S2 ).

Fig. 3

3.10. Effect of metal dispersion upon polyol-functionalized cellulose

Similar antibacterial tests were also performed with cellulose-based samples against both E. coli and Bacillus (Fig. S13) . Untreated cellulose denoted as CT and its polyol-functionalized counterpart (H20@CT) showed no antibacterial activity. Here also, the mere insertion of metal in both oxidation states induced antibacterial properties. The strong activity of $\mathrm{Cu}$-loaded cellulose matrices against bacteria can be illustrated by inhibition zone diameters of $1.6 \mathrm{~cm}$ for $\mathrm{Cu}^{0} / \mathrm{CT}$ and $1-3.5 \mathrm{~cm}$ for $\mathrm{Cu}^{0} / \mathrm{H} 20 @ \mathrm{CT}$ (Table 4). This confirms once again the beneficial role of dendrimer H20 incorporation favoring CuNP dispersion. Silver-based samples are less effective as antimicrobial agents against both $B . \sigma v \beta \tau \imath \imath \iota$ av $E$. solı $\Delta H 5 a, \omega$ hich can be related to a stronger $\mathrm{HO}: \mathrm{Ag}$ interaction compared to $\mathrm{HO}: \mathrm{Cu}$ interaction as supported by TPD measurements

\section{Table 4}

\subsection{Action of Metal NPs against bacteria}

The external side of the cell wall of both Gram-positive and Gram-negative bacteria bears negative charges due to the presence of functional groups like carboxyl and phosphate and hydroxyl (Ashmore et al., 2018). Gram-positive bacteria possess a thick peptidoglycan layer, which resides in linear chains alternating residues of $\mathrm{N}$-acetylglucosamine (NAG) and N-acetylmuramic acid (NAM) linked together by a sequence of 3 to 5 amino acids that cross-link each other, giving rise to a cohesive mesh. Additionally, negatively charged teichoic acids (with high levels of phosphate groups) are spread from the cell wall to the surface of most Grampositive bacteria (Scheme S4.a) . In contrast, Gram-negative bacteria display more complex structure with a thinner layer of peptidoglycan and a phospholipid outer membrane with partially phosphorylated lipopolysaccharides (LPS) that contribute to raise the negative surface charge (Scheme S4.b) (Stensberg et al., 2011).

Negatively charged bacterial cell walls interact with positively charged particles such as metal cations via electrostatic interactions. Cations may act through diverse pathways among which two seem to prevail in aqueous media: (i) strong electrostatic interaction that alter bacteria membrane equilibrium, and (ii) Lewis acid-base 
interaction with water molecules that generates Bronsted acidity $\left(\mathrm{M}^{\mathrm{n}+}+\mathrm{xH}_{2} \mathrm{O}=\left[\mathrm{M}\left(\mathrm{H}_{2} \mathrm{O}\right)_{(\mathrm{x}-1)} \mathrm{OH}\right]^{(\mathrm{n}-1)+}+\right.$ $\mathrm{H}^{+}$) that may alter bacteria membrane. The metal ions are then free to interact with cellular structures (e.g.,proteins, membranes, DNA), disrupting cell functions (Ashmore et al., 2018). In contrast, MNPs are supposed to interact via strong LAB interaction with atoms bearing available electron pairs $(\mathrm{O}, \mathrm{S}$, and $\mathrm{N})$ that act as Lewis base. Such interactions are assumed to affect the normal cell exchange through bacteria membrane. Other mechanisms such MNP diffusion inside the cell and disrupt biological processes (Stensberg et al., 2011). Inside the cell, both metal cation and nanoparticles can generate reactive oxygen species (ROS) like hydrogen peroxide $\left(\mathrm{H}_{2} \mathrm{O}_{2}\right.$, superoxide anion $\left(\cdot \mathrm{O}_{2}{ }^{-}\right)$, and hydroxyl radical ${ }^{*} \mathrm{OH}$ (Gordon et al., 2010; Yun'an Qing et al., 2018). These species are assumed to bind to phosphate groups inhibiting protein phosphorylation frequently involved in enzymatic activation. This is expected to inhibit bacterial growth and cell cycle through the dephosphorylation of some important proteins for enzymatic activities (Dakal, Kumar, Majumdar, \& Yadav, 2016). Given that metals bind to biomolecules through non-specific interactions, MNPs generally exhibit a wide variety of processes against bacteria (Scheme S4.c) (Yuan, Ding, Yang, \& Xu, 2018).

Once inside the cell, both AgNPs and $\mathrm{Ag}^{+}$ions interact with diverse species resulting in cell dysfunction. Reportedly, AgNPs can act through four main mechanism pathways: (i) attraction on bacterial surface; (ii) destabilization of the bacterial cell wall and increase in membrane permeability even for larger AgNPs (Losasso et al., 2014); (iii) genesis of ROS and free radicals that induce toxicity and oxidative stress; (iv ) modification of signal transduction pathways (Dakal et al., 2016). AgNP adsorption on the bacterial surface can be followed by diffusion of smaller particle inside the cell and retention of larger ones on the external side of the bacteria membrane. In spite of their antibacterial activity (Avalos, Haza, Mateo, \& Morales, 2013), AgNPs were found to be less performant that cations (El Badawy et al., 2011). The latter are much more attracted by the negative charges of bacterial walls (Slavin, Asnis, Hafeli, \& Bach, 2017). However, AgNPs may also act through partial dissolution into $\mathrm{Ag}^{+}$cations, as reported by many works. $\mathrm{The}^{\mathrm{Ag}^{+}}$cations act differently by binding to the cell membrane inducing changes in the membrane potential and proton leakage (Losasso et al., 2014). Reportedly, $\mathrm{Ag}^{+}$cation may intercalate DNA segments generating complexes with nucleotides and disrupting H-bonds between base pairs (Yun'an Qing et al., 2018). Similar observations were made for CuNPs where a $\mathrm{Cu}^{2+}$ release was found to be the main contribution to the high antibacterial activity (Chatterjee, Chakraborty, \& Basu, 2014; Sistematica, Gabriela, Daniela, \& Helia, 2016). As for silver, CuNP action may also involve diverse mechanisms, the most reported by the literature being: (i ) CuNP concentration and dissolution in the bacterial membrane inducing potential and permeability changes, with unavoidable leak in lipopolysaccharides, membrane proteins, intracellular biomolecules and protons (Amro et al., 2000; Azam, Ahmed, Oves, Khan, \& Memic, 2012). (ii) production of ROS, MNPs oxidation and dissolution into $\mathrm{Cu}^{2+}$ cation, with other detrimental oxidative processes (Fenton, Harber-Weiss) processes (Applerot et al., 2012; Fang, Lyon, Wiesner, Dong, \& Alvarez, 2007); (iii) Accumulation of $\mathrm{Cu}^{2+}$ cation with decay in intracellular ATP production and disruption of DNA replication (Kim et al., 2007; Sondi \& SalopekSondi, 2004). These pathways should confer higher activity to CuNPs against both bacteria compared with AgNPs (Chudobova \& Kizek, 2015).

\section{Conclusion}

Metal dispersion in the form of AgNPs and CuNPs with polyol dendrimer resulted in higher antibacterial activity than merely spread on a solid surface of montmorillonite or cellulose fibers. Both cellulose and clay act as host matrices for MNP when previously coated by BoltornH20. Polyol dendrimer incorporation induces no detectable antibacterial activity but provides additional hydroxyl groups that act as chelating agents for both MNPs and metal cations. The strength of the-HO:Metal interaction plays a key-role in metal retention/release processes and, subsequently, in the antibacterial activity of the metal loaded polyol-clay or polyol-cellulose composite against both Gram-positive and Gram-negative bacteria. Weaker retention of CuNPs and its involvement in oxidative damage explains, at least in part, the higher antibacterial activity of CuNPs as compared to silver counterparts. The occurrence of an optimal amount of metal-loaded polyol composites for achieving a high biocidal effect is attributed to structure compaction and diffusion hindrance of metal species at abundant number of -OH groups incorporated. Research is still in progress for designing 
even more effective antibacterial matrices with natural and low-cost materials and modulable entanglement porosity.

Acknowledgements: This work was supported by NSERC (To Pr. Mircea A. Mateescu). The authors appreciate the technical assistance of Dr. G. Chamoulaud (Nanoqam), Dr. Alain Adnot (Laval University) and Dainelys Guadarrama Bello (UdeM).

\section{References:}

Amro, N. A., Kotra, L. P., Wadu-Mesthrige, K., Bulychev, A., Mobashery, S., \& Liu, G.-y. (2000). Highresolution atomic force microscopy studies of the Escherichia coli outer membrane: structural basis for permeability. Langmuir, 16 (6), 2789-2796.

Applerot, G., Lellouche, J., Lipovsky, A., Nitzan, Y., Lubart, R., Gedanken, A., \& Banin, E. (2012). Understanding the antibacterial mechanism of $\mathrm{CuO}$ nanoparticles: revealing the route of induced oxidative stress. Small, 8 (21), 3326-3337.

Ashmore, D. A., Chaudhari, A., Barlow, B., Barlow, B., Harper, T., Vig, K., . . . Pillai, S. (2018). Evaluation of E. coli inhibition by plain and polymer-coated silver nanoparticles. Revista do Instituto de Medicina Tropical de Sao Paulo, 60 .

Avalos, A., Haza, A., Mateo, D., \& Morales, P. (2013). Nanoparticulas de plata: aplicaciones y riesgos toxicos para la salud humana y el medio ambiente/Silver nanoparticles: applications and toxic risks to human heatlh and environment. Revista Complutense de Ciencias Veterinarias, 7 (2), 1.

Azam, A., Ahmed, A. S., Oves, M., Khan, M., \& Memic, A. (2012). Size-dependent antimicrobial properties of $\mathrm{CuO}$ nanoparticles against Gram-positive and-negative bacterial strains. International journal of nanomedicine, 7 , 3527.

Azzouz, A., Assaad, E., Ursu, A.-V., Sajin, T., Nistor, D., \& Roy, R. (2010). Carbon dioxide retention over montmorillonite-dendrimer materials. Applied Clay Science, 48 (1-2), 133-137.

Azzouz, A., Nistor, D., Miron, D., Ursu, A., Sajin, T., Monette, F., . . . Hausler, R. (2006). Assessment of acid-base strength distribution of ion-exchanged montmorillonites through NH3 and CO2-TPD measurements. Thermochimica Acta, 449 (1-2), 27-34.

Beltrao-Nunes, A.-P., Sennour, R., Arus, V.-A., Anoma, S., Pires, M., Bouazizi, N., . . . Azzouz, A. (2019). $\mathrm{CO} 2$ capture by coal ash-derived zeolites-roles of the intrinsic basicity and hydrophilic character. Journal of Alloys and Compounds, 778 , 866-877.

Bragg, P., \& Rainnie, D. (1974). The effect of silver ions on the respiratory chain of Escherichia coli. Canadian journal of microbiology, 20 (6), 883-889.

Carretero, M. I. (2002). Clay minerals and their beneficial effects upon human health. A review. Applied Clay Science, 21 (3-4), 155-163.

Chatterjee, A. K., Chakraborty, R., \& Basu, T. (2014). Mechanism of antibacterial activity of copper nanoparticles. Nanotechnology, 25 (13), 135101.

Chudobova, D., \& Kizek, R. (2015). Nanotechnology in diagnosis, treatment and prophylaxis of infectious diseases. Journal of Metallomics and Nanotechnologies, 2 , 67-69.

Čık, G., Bujdáková, H., \& Šeršeň, F. (2001). Study of fungicidal and antibacterial effect of the Cu (II)complexes of thiophene oligomers synthesized in ZSM-5 zeolite channels. Chemosphere, 44 (3), 313-319.

Č́́k, G., Priesolová, S., Bujdáková, H., Šeršeň, F., Potheöová, T., \& Krištín, J. (2006). Inactivation of bacteria G+-S. aureus and G-E. coli by phototoxic polythiophene incorporated in ZSM-5 zeolite. Chemosphere, 63 (9), 1419-1426. 
Costa, C., Conte, A., Buonocore, G. G., \& Del Nobile, M. A. (2011). Antimicrobial silver-montmorillonite nanoparticles to prolong the shelf life of fresh fruit salad. International Journal of Food Microbiology, 148 (3), 164-167.

Cragg, G. M., \& Newman, D. J. (2013). Natural products: a continuing source of novel drug leads. Biochimica et Biophysica Acta (BBA)-General Subjects, 1830 (6), 3670-3695.

Crooks, R. M., Zhao, M., Sun, L., Chechik, V., \& Yeung, L. K. (2001). Dendrimer-encapsulated metal nanoparticles: synthesis, characterization, and applications to catalysis. Accounts of chemical research, 34 (3), 181-190.

Dakal, T., Kumar, A., Majumdar, R., \& Yadav, V. (2016). Mechanistic basis of antimicrobial actions of silver nanoparticles. Front Microbiol. 2016; 7: 1831. In.

Dizman, B., Badger, J. C., Elasri, M. O., \& Mathias, L. J. (2007). Antibacterial fluoromicas: a novel delivery medium. Applied Clay Science, 38 (1-2), 57-63.

El Badawy, A. M., Silva, R. G., Morris, B., Scheckel, K. G., Suidan, M. T., \& Tolaymat, T. M. (2011). Surface charge-dependent toxicity of silver nanoparticles. Environmental science $\mathcal{E}$ technology, 45 (1), 283-287.

Espana, V. A. A., Sarkar, B., Biswas, B., Rusmin, R., \& Naidu, R. (2019). Environmental applications of thermally modified and acid activated clay minerals: current status of the art. Environmental Technology $\mathcal{E}$ Innovation, 13 , 383-397.

Fang, J., Lyon, D. Y., Wiesner, M. R., Dong, J., \& Alvarez, P. J. (2007). Effect of a fullerene water suspension on bacterial phospholipids and membrane phase behavior. Environmental science $\&$ technology, $41(7), 2636-2642$.

Fu, F., Li, L., Liu, L., Cai, J., Zhang, Y., Zhou, J., \& Zhang, L. (2015). Construction of cellulose based ZnO nanocomposite films with antibacterial properties through one-step coagulation. ACS applied materials 83 interfaces, 7 (4), 2597-2606.

Gordon, O., Slenters, T. V., Brunetto, P. S., Villaruz, A. E., Sturdevant, D. E., Otto, M., . . . Fromm, K. M. (2010). Silver coordination polymers for prevention of implant infection: thiol interaction, impact on respiratory chain enzymes, and hydroxyl radical induction. Antimicrobial agents and chemotherapy, 54 (10), 4208-4218.

Gupta, A., Maynes, M., \& Silver, S. (1998). Effects of halides on plasmid-mediated silver resistance in Escherichia coli. Appl. Environ. Microbiol., 64 (12), 5042-5045.

Hellmann, J., Hamano, M., Karthaus, O., Ijiro, K., Shimomura, M., \& Irie, M. (1998). Aggregation of dendrimers with a photochromic dithienylethene core group on the mica surface-atomic force microscopic imaging. Japanese journal of applied physics, 37 (7A), L816.

Herrera, P., Burghardt, R., \& Phillips, T. (2000). Adsorption of Salmonella enteritidis by cetylpyridiniumexchanged montmorillonite clays. Veterinary microbiology, 74 (3), 259-272.

Joshi, M., Purwar, R., Udakhe, J. S., \& Sreedevi, R. (2015). Antimicrobial nanocomposite compositions, fibers and films. In: Google Patents.

Kim, J. S., Kuk, E., Yu, K. N., Kim, J.-H., Park, S. J., Lee, H. J., . . . Hwang, C.-Y. (2007). Antimicrobial effects of silver nanoparticles.Nanomedicine: Nanotechnology, Biology and Medicine, 3 (1), 95-101.

Komadel, P. (2016). Acid activated clays: Materials in continuous demand. Applied Clay Science, 131, 84-99.

Levy, S. B. (1998). The challenge of antibiotic resistance.Scientific American, 278 (3), 46-53. 
Losasso, C., Belluco, S., Cibin, V., Zavagnin, P., Mičetić, I., Gallocchio, F., . . . Ricci, A. (2014). Antibacterial activity of silver nanoparticles: sensitivity of different Salmonella serovars. Frontiers in microbiology, 5 , 227.

Martin, S., \& Griswold, W. (2009). Human health effects of heavy metals. Environmental Science and Technology briefs for citizens, $15,1-6$.

Nabil, B., Christine, C., Julien, V., \& Abdelkrim, A. (2018). Polyfunctional cotton fabrics with catalytic activity and antibacterial capacity. Chemical Engineering Journal, 351 , 328-339.

Nadziakiewicza, M., Kehoe, S., \& Micek, P. (2019). Physico-Chemical Properties of Clay Minerals and Their Use as a Health Promoting Feed Additive. Animals, 9 (10), 714.

Potera, C. (2012). Understanding the germicidal effects of silver nanoparticles. In: National Institute of Environmental Health Sciences.

Rai, M., Yadav, A., \& Gade, A. (2009). Silver nanoparticles as a new generation of antimicrobials. Biotechnology advances, 27 (1), 76-83.

Rees, N. V., Zhou, Y. G., \& Compton, R. G. (2011). The aggregation of silver nanoparticles in aqueous solution investigated via anodic particle coulometry. ChemPhysChem, 12 (9), 1645-1647.

Sistemática, D. d. C. R. R., Gabriela, S.-S., Daniela, F.-R., \& Helia, B.-T. (2016). Copper Nanoparticles as Potential Antimicrobial Agent in Disinfecting Root Canals. A Systematic Review. Int. J. Odontostomat, 10 (3), 547-554.

Slavin, Y. N., Asnis, J., Häfeli, U. O., \& Bach, H. (2017). Metal nanoparticles: understanding the mechanisms behind antibacterial activity. Journal of nanobiotechnology, 15 (1), 65.

Sondi, I., \& Salopek-Sondi, B. (2004). Silver nanoparticles as antimicrobial agent: a case study on E. coli as a model for Gram-negative bacteria. Journal of colloid and interface science, 275 (1), 177-182.

Stavitskaya, A., Batasheva, S., Vinokurov, V., Fakhrullina, G., Sangarov, V., Lvov, Y., \& Fakhrullin, R. (2019). Antimicrobial applications of clay nanotube-based composites. Nanomaterials, 9 (5), 708.

Stensberg, M. C., Wei, Q., McLamore, E. S., Porterfield, D. M., Wei, A., \& Sepúlveda, M. S. (2011). Toxicological studies on silver nanoparticles: challenges and opportunities in assessment, monitoring and imaging. Nanomedicine, 6 (5), 879-898.

Sulpizi, M., Gaigeot, M. P., \& Sprik, M. (2012). The Silica-Water Interface: How the Silanols Determine the Surface Acidity and Modulate the Water Properties. J Chem Theory Comput, 8 (3), 1037-1047. doi:10.1021/ct2007154

Terrab, I., Boukoussa, B., Hamacha, R., Bouchiba, N., Roy, R., Bengueddach, A., \& Azzouz, A. (2016). Insights in CO2 interaction on zeolite omega-supported polyol dendrimers. Thermochimica Acta, 624 , 95101.

Thuc, C.-N. H., Grillet, A.-C., Reinert, L., Ohashi, F., Thuc, H. H., \& Duclaux, L. (2010). Separation and purification of montmorillonite and polyethylene oxide modified montmorillonite from Vietnamese bentonites.Applied Clay Science, 49 (3), 229-238.

Vdović, N., Jurina, I., Škapin, S. D., \& Sondi, I. (2010). The surface properties of clay minerals modified by intensive dry milling - revisited. Applied Clay Science, 48 (4), 575-580.

Vincent, M., Duval, R. E., Hartemann, P., \& Engels-Deutsch, M. (2018). Contact killing and antimicrobial properties of copper. Journal of Applied microbiology, 124 (5), 1032-1046.

Williams, L. B., Metge, D. W., Eberl, D. D., Harvey, R. W., Turner, A. G., Prapaipong, P., \& PoretPeterson, A. T. (2011). What makes a natural clay antibacterial? Environmental science $\mathcal{E}$ technology, 45 (8), 3768-3773. 
Yuan, P., Ding, X., Yang, Y. Y., \& Xu, Q. H. (2018). Metal nanoparticles for diagnosis and therapy of bacterial infection. Advanced healthcare materials, 7 (13), 1701392.

Yun'an Qing, L. C., Li, R., Liu, G., Zhang, Y., Tang, X., Wang, J., . . . Qin, Y. (2018). Potential antibacterial mechanism of silver nanoparticles and the optimization of orthopedic implants by advanced modification technologies. International journal of nanomedicine, 13, 3311.

\section{Tables}

Table 1. $\mathrm{CO}_{2}$ retention capacity $\left(\mathrm{mmol}_{\mathrm{g}} \mathrm{g}^{-1}\right)$ for the synthesized clay and CT-based samples

\begin{tabular}{lllll}
\hline Clay samples & CRC & WRC & CT samples & CRC \\
\hline Bentonite & 2101.082 & $1.2282 \mathrm{E}-05$ & $\mathrm{CT}$ & - \\
NaMt & 2261.979 & $2.0257 \mathrm{E}-06$ & $\mathrm{H} 20 @ \mathrm{CT}$ & 38.35921 \\
$\mathrm{Ash}$ & 1752.185 & $1.91539 \mathrm{E}-06$ & $\mathrm{Cu}^{0} / \mathrm{H} 20 @ \mathrm{CT}$ & 14.54479 \\
$\mathrm{Cu}^{0} / \mathrm{NaMt}$ & 55.418 & - & $\mathrm{Ag}^{0} / \mathrm{H} 20 @ \mathrm{CT}$ & 5.661805 \\
$\mathrm{Ag}^{0} \mathrm{NaMt}$ & 662.8791 & - & & \\
\hline
\end{tabular}

Table 2. Weight loss of clay and cellulose-based samples for different temperature ranges.

\begin{tabular}{lll}
\hline Sample & Temperature $\left({ }^{\circ} \mathrm{C}\right)$ & Wight loos $(\%)$ \\
\hline $\mathrm{NaMt}$ & $40-90$ & $0.7-0.8$ \\
$\mathrm{Cu}^{0} / \mathrm{NaMt}$ & $140-480$ & 6.6 \\
$\mathrm{Ag}^{0} / \mathrm{NaMt}$ & $90-470$ & 9.4 \\
$\mathrm{CT}$ & $47-130$ & $0-0.1$ \\
$\mathrm{H} 20 @ \mathrm{CT}$ & $47-185$ & 0.275 \\
$\mathrm{Cu}^{0} / \mathrm{CT}$ & $43-190$ & 8.25 \\
$\mathrm{Ag}^{0} / \mathrm{CT}$ & $47-200$ & 8.74 \\
$\mathrm{Cu}^{0} / \mathrm{H} 20 @ \mathrm{CT}$ & $32-200$ & 4.675 \\
$\mathrm{Ag}^{0} / \mathrm{H} 20 @ \mathrm{CT}$ & $40-200$ & 8.525 \\
\hline
\end{tabular}

Table 3. Binding energy (eV) shifts for key elements in the synthesized materials

\begin{tabular}{llllll}
\hline Element's name & Binding energy $(\mathrm{eV})$ & Binding energy $(\mathrm{eV})$ & Binding energy $(\mathrm{eV})$ & Binding energy $(\mathrm{eV})$ & Binding ener \\
\hline & $\mathrm{NaMt}$ & $\mathrm{Cu}^{0} / \mathrm{NaMt}$ & $\mathrm{Ag}^{0} / \mathrm{NaMt}$ & $\mathrm{CT}$ & $\mathrm{H} 20 @ \mathrm{CT}$ \\
$\mathrm{O} 1 \mathrm{~s}$ & 532.55 & 531 & 527 & 533 & 532 \\
$\mathrm{C} 1 \mathrm{~s}$ & 285.55 & 285 & 285 & 285 & 285 \\
$\mathrm{Al} 2 \mathrm{~s}$ & 115 & 85.6 & 75.55 & - & - \\
$\mathrm{Si} 2 \mathrm{~s}$ & 154.55 & 103 & 149 & - & - \\
$\mathrm{Ag} \mathrm{3d}$ & - & - & 364 & - & - \\
$\mathrm{Cu} 2 \mathrm{p}$ & - & 933 & - & - & - \\
$\mathrm{Ca} 2 \mathrm{~s}$ & 439.55 & - & - & & - \\
$\mathrm{Fe} 2 \mathrm{p}$ & 714.55 & - & 709 & & \\
\hline
\end{tabular}

Table 4. Bacterial inhibition diameters $(\mathrm{cm})$ and antibacterial activity evaluation for various studied CTbased systems

\begin{tabular}{llllll}
\hline Investigated & $\mathrm{CT}$ & Boltorn & $\mathrm{TM}$ \\
$\mathrm{H} 20 \mathrm{H} 20 @ \mathrm{CT}$ & $\mathrm{Ag}^{0} / \mathrm{CT}$ & $\mathrm{Cu}^{0} / \mathrm{CT}$ & $\mathrm{Cu}^{0} / \mathrm{H} 20 @ \mathrm{CT}$ & $\mathrm{Ag}^{0} / \mathrm{H} 20 @ \mathrm{CT}$
\end{tabular}
system 


\begin{tabular}{|c|c|c|c|c|c|c|c|}
\hline $\begin{array}{l}\text { Bacillus } \\
(\mathrm{cm})\end{array}$ & - & - & - & 1 & 1.6 & 3.5 & 2 \\
\hline $\begin{array}{l}\text { Antibacterial } \\
\text { activity }\end{array}$ & No & No & No & Strong & Strong & Strong & Strong \\
\hline E. $\operatorname{coli}(\mathrm{cm})$ & - & - & - & - & 0.5 & 1 & 0.9 \\
\hline $\begin{array}{l}\text { Antibacterial } \\
\text { activity }\end{array}$ & No & No & No & No & Weak & Strong & Weak \\
\hline
\end{tabular}

\section{Figure \& Scheme captions}

Scheme 1. Schematic illustration of NaMt based samples before (H20@NaMt) and after metal dispersion (Metal/H20@NaMt) (a) and of $\mathrm{CT}$ based samples before (H20@CT) and after metal dispersion (Metal/H20@CT) (b).

Fig. 1. SEM of unloaded and of metal loaded NaMt and H20@CT (a) and of untreated cellulose (CT), polyol-functionalized cellulose (H20@CT), metal zero-loaded cellulose (MNPs/CT and MNPs/H20@CT) (b).

Fig. 2. XPS graphs of untreated NaMt and metal loaded counterparts (a) and of two key elements (Al2p, $\mathrm{Si} 2 \mathrm{p})$ for both NaMt and $\mathrm{Ag}^{\mathrm{O}} / \mathrm{NaMt}(\mathrm{b})$.

Fig. 3. Effect of untreated matrices on Bacillus Subtilis168 proliferation . Bacteria strain was incubated for $24 \mathrm{~h}$ at $37^{\circ} \mathrm{C}$ with $5 \mathrm{mg}$ of untreated clays NaMt (left dish), Boltorn ${ }^{\mathrm{TM}} \mathrm{H} 20$ (middle dish) and H20@NaMt (right dish) (a). Average diameter and dependence of inhibition zone of $\boldsymbol{E}$. coli and B. subtilis treated with various amounts of antibacterial agents. All Petri dishes were incubated for $24 \mathrm{~h}$ at $37^{\circ} \mathrm{C}$ with a cell density of 0.5 at $600 \mathrm{~nm}(\mathrm{~b})$.

Fig. 4. Antibacterial test of $\mathbf{A g}^{0} / \mathrm{NaMt}$ and $\mathrm{Cu}^{\mathbf{0}} / \mathrm{NaMt}$ clay- based samples . Escherichia coli(a1 and b1), Bacillus subtilis168 (a2 and b2) were incubated for $24 \mathrm{~h}$ at $37{ }^{\circ} \mathrm{C}$ with $5 \mathrm{mg}$ of $\mathrm{Cu}^{0} / \mathrm{NaMt}$ (a1-2) or $\mathrm{Ag}^{0} / \mathrm{NaMt}(\mathrm{b} 1-2)$.

Fig. 5. Antibacterial test of MNP loaded in organoclay- based samples . Escherichia coli (a1, $\mathrm{b} 1, \mathrm{c} 1$ and d1),Bacillus subtilis168 (a2, b2, c2 and d2) were incubated for $24 \mathrm{~h}$ at $37{ }^{\circ} \mathrm{C}$ with $5 \mathrm{mg}$ of $\mathrm{Ag}^{0} / \mathrm{H} 20 @ \mathrm{NaMt}$ (a1-2); $\mathrm{Cu}^{0} / \mathrm{H} 20 @ \mathrm{NaMt}$ (b1-2); $\mathrm{Ag}^{+} / \mathrm{H} 20 @ \mathrm{NaMt}$ (c1-2) and $\mathrm{Cu}^{2+} / \mathrm{H} 20 @ \mathrm{NaMt}(\mathrm{d} 1-2)$.

\section{Hosted file}

Figures \& Schemes.docx available at https://authorea.com/users/338170/articles/464175-metalloaded-porous-polyhydroxylic-matrices-with-improved-antibacterial-properties 